This article was downloaded by: University of Auckland

On: 15 Oct 2018

Access details: subscription number 10999

Publisher:Routledge

Informa Ltd Registered in England and Wales Registered Number: 1072954 Registered office: 5 Howick Place, London SW1P 1WG, UK

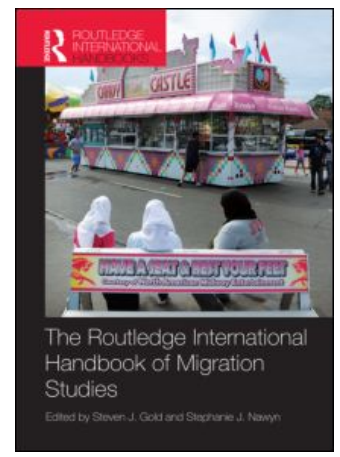

\title{
Routledge International Handbook of Migration Studies
}

Steven J. Gold, Stephanie J. Nawyn

Host hostility and nativism

Publication details

https://www.routledgehandbooks.com/doi/10.4324/9780203863299.ch16

Mehdi Bozorgmehr, Anny Bakalian, Sara Salman

Published online on: 13 Dec 2012

How to cite :- Mehdi Bozorgmehr, Anny Bakalian, Sara Salman. 13 Dec 2012 ,Host hostility and nativism from: Routledge International Handbook of Migration Studies Routledge.

Accessed on: 15 Oct 2018

https://www.routledgehandbooks.com/doi/10.4324/9780203863299.ch16

\section{PLEASE SCROLL DOWN FOR DOCUMENT}

Full terms and conditions of use: https://www.routledgehandbooks.com/legal-notices/terms.

This Document PDF may be used for research, teaching and private study purposes. Any substantial or systematic reproductions, re-distribution, re-selling, loan or sub-licensing, systematic supply or distribution in any form to anyone is expressly forbidden.

The publisher does not give any warranty express or implied or make any representation that the contents will be complete or accurate or up to date. The publisher shall not be liable for an loss, actions, claims, proceedings, demand or costs or damages whatsoever or howsoever caused arising directly or indirectly in connection with or arising out of the use of this material. 


\section{Host hostility and nativism}

Mehdi Bozorgmehr, Anny Bakalian, and Sara Salman

\section{Introduction}

Host hostility and nativism have not received much conceptual and theoretical attention from researchers. Consequently, there are few publications on the topic. The purpose of this chapter is to survey and bring together the disparate descriptive and historical literatures. We focus on hostility and nativism directed against immigrants and refugees (i.e., the foreign born) or people of immigrant stock (first and second generation). We examine the US experience in detail and compare it with other major immigrant-receiving advanced industrial countries in Europe. We first define concepts that are subsumed under the rubric of host hostility such as nativism, racism, xenophobia, and its specific variant Islamophobia. We compare and contrast how newcomers were treated during the two massive immigration waves that occurred both at the turn of twentieth century (1880-1930) and in the twenty-first century (1965 to present) in the USA. We use landmark cases to illustrate how the interests of the host population (majority and native-born minorities) resulted in hostility against immigrants at various periods triggered by economic, political or social motives. Next, we review the key sociological theories of intergroup conflict. We conclude with a discussion of the consequences of host hostilities. While restrictive immigration laws that limit entry to migrants are exclusionary, they do not directly pertain to immigrants already living in host societies and therefore are not included in our analysis.

\section{Conceptual definitions and clarifications}

The "host" in host hostility has been traditionally conceptualized from the perspective of a society vis-à-vis newcomers (Jaret 2002). This has sometimes but not often encompassed the state and its policies (Joppke 2010). While the host society is viewed as a monolith, in reality it is highly stratified by power relations between majority and minority groups. The majority population wields greater power because it has access to valued, yet scarce, resources. Minority groups are disadvantaged in comparison to the powerful majority population adversely affecting their upward mobility (Olzak and Nagel 1986).

Racism is exercised when the members of a group are treated unequally based on their affiliation instead of their individual characteristics and qualities. It is a practice that subordinates 


\section{Bozorgmehr et al.}

victimized groups and hinders their upward mobility. Traditional racism is the belief that some groups are inherently superior to others in intelligence, temperament, and attitude as well as physically. "New racism" is cultural rather than biological, using the values of the dominant society to marginalize groups that resist assimilation. While prejudice and discrimination are often used simultaneously and interchangeably, prejudice refers to attitude while discrimination signifies action and behavior. Prejudiced attitudes often take the form of scapegoating and stereotypes. Discriminatory behaviors include bias incidents, which are motivated by the offender's prejudice against the group, and hate crimes, which are acts of violence committed against people, organizations, or property. Starting in the 1980s, hate-crime statutes were first enacted in the USA and the UK, acknowledging that a significant number of crimes against persons and property were motivated by hate (Min 2005).

In his classic book, Strangers in the Land, John Higham (1955) defined nativism as zealous opposition to minorities because of perceived un-American characteristics. Nativists draw on ethnocentric assumptions about outsiders and seek to protect a nation's values and traditions from foreigners and intruders. In other words, nativism is not simply a synonym for racism; it is a sentiment that is imbued with threatened nationalism. Nativism is exogenous, whereas racism can be both endogenous and exogenous. Xenophobia is a form of racism that is characterized by the hatred or fear of foreigners. Islamophobia, the dread of Islam and all Muslims, is a specific example of xenophobia (Modood 2005) which has intensified in the aftermath of $9 / 11$ and 7/7 in the UK.

\section{Old and new nativism}

Despite the fact that the USA is a nation of immigrants, newcomers continue to face hostilities from native-born Americans. Ironically, members of ethnic groups whose immigrant ancestors were discriminated against are capable of engaging in hostility and violence against the newest arrivals. Studying immigration history in the USA demonstrates recurring nativist sentiments and discriminatory behaviors. We use two major waves of immigration in American history-the first during the turn of the twentieth century (1880-1930) and the second post-1965-to compare and contrast old and new nativism (also see Jaret 2002). By the 1880s, the national origins of the majority of immigrants had shifted from Northern and Western Europeans to Southern, Central, and Eastern Europeans. Moreover, this wave was mostly Catholic, Jewish, and Orthodox Christian, making them different from the dominant White Anglo-Saxon Protestant (WASP) population. The newcomers were mostly peasants or artisans, generally with little formal education and knowledge of English.

By the first decade of the twentieth century, there were already signs that the economic boom was slowing, almost to a halt. Immigration was partly blamed for the woes of the nation. There were attempts to curtail new immigration, but legislation had to await the end of World War I. The National Origin's Act of 1924 established immigration quotas for each country using the 1890 census as a yardstick for the desirable composition of the nation. Since there were few immigrants from Southern and Eastern Europe before the 1880s, a new influx from these regions was dramatically curtailed until 1965 when these laws were revoked. In the decades between the first large wave of immigration and the second, the USA suffered the Great Depression and World War II (Zolberg 2006). During this period, with the immigration door almost shut, migration chains between the pioneers and subsequent waves were broken. Allowing enough time for full assimilation was part of the original motivation to stem the tide of immigration.

In contrast to the first wave, the post-1965 immigrants have been coming from Asia, South and Central America, the Caribbean, Africa, and the Middle East. Moreover, unlike their predecessors, 
newcomers' socioeconomic characteristics are more diverse. While some are highly educated professionals admitted under employment preferences, others are labor migrants with minimal education. Additionally, larger numbers of immigrants have arrived with some English fluency (Portes and Rumbaut 2006). In terms of religiosity, today's immigrants cover a wide range of religious persuasions.

The most recent immigrants to the USA enter a post-industrial society where the dual economy requires highly specialized workers in the primary sector as well as cheap labor in the secondary sector. Consequently, contemporary immigrants include professionals in health care, information technology, as well as entrepreneurs. At the other end of the spectrum, labor migrants have found menial employment as maids, manicurists, busboys, and garage attendants.

Globalization as a phenomenon has further changed the profile of new immigrants. Today, most arrive with prior exposure to technology, travel, and communication skills. Not only are the immigrants entering a society that is more welcoming and multicultural, they are also able to maintain transnational relations with their homelands, thereby resisting assimilation. As importantly, since the civil rights movement of the 1960s and the ethnic revival movement in the 1970s and 1980s, pluralism is now the dominant current ideology, as opposed to assimilation and Americanization during the classic era of immigration (1880-1930) (Alba and Nee 2003). All these differences have implications for the new immigrants and the society as a whole in the face of old and new nativism.

At the turn of the twentieth century, religious difference was a major source of nativism (Jaret 2002). The majority Protestant population and elites believed that Catholics were incapable of independent thought because they confessed to a priest and obeyed the Pope, their spiritual father. In contrast, Protestants believed that they were more rational and free because of their unmediated relationship with God. While anti-Semitism has been prevalent in US history, it escalated when over two million Jews arrived from Eastern European shtetls. In contrast to the affluent German Jews who had preceded them, the newcomers were less educated, Yiddish speaking, and congregated in tenements in New York City. The Americanized Jews established self-help organizations to change their coreligionists' peasant manners and help them assimilate. Nonetheless, anti-Semitism from the host society persisted affecting the social mobility of second generation Jews. In the early decades of the twentieth century, social clubs and resorts banned Jews from membership, big law firms and corporations denied them employment, and Ivy League universities imposed a quota on Jewish students (Diner 1999). Anti-Semitism against European Jews has a long history, but everything pales when compared to the Nazi ideology that cost the lives of over six million Jews in the Holocaust. Yet after Germany acknowledged its wrongdoing and paid reparations, German neo-Nazi and far-right skinheads have made a comeback, many decorated with symbols smuggled from America. Since the 1990s, they have been attacking refugee centers, murdering Turkish women, and terrorizing visibly Muslim persons and places (Castles and Miller 2008).

Antiradicalism was another nativist sentiment that emerged in the first half of the twentieth century. Their targets were Bolsheviks, anarchists, and communists. Many native-born Americans believed that foreigners would bring about the destruction and destabilization of the country's institutions and threaten American democracy. In 1919, when bombs were mailed to prominent national leaders across the country, including one that partially destroyed the house of US Attorney A. Mitchell Palmer, the Bolsheviks or "the Red Menace" were believed to be the culprits. Palmer and J. Edgar Hoover, his young assistant, imprisoned and deported many Bolsheviks and radicals (Camp 1995; Gerstle 2004).

Even though the USA has been a more welcoming society to the post-1965 immigrants, hostilities continue to erupt at times of economic and political crises. Economic crises can be felt 


\section{Bozorgmehr et al.}

at both local and national levels, whereas political crises are often felt at the national level. In particular, immigrants who share the ethnic and religious characteristics of the "enemies" of the state become the victims of backlash. The internment of Japanese Americans was one of the most egregious episodes of host hostility in US history, built on exclusionary legislation and rampant anti-Asian racism in the West. After the attack on Pearl Harbor in 1941, President Roosevelt passed Executive Order 9066, mandating approximately 120,000 Japanese Americans to be sent to "war relocation camps" for about four years on the grounds that they can spy for the Japanese government. The order detained all men, women, and children of Japanese descent in the western coastal regions. Two-thirds were the US-born (nisei) and citizens (Daniels 1972, 1988).

In the first decade of the twenty-first century, Islamophobia has emerged as a dominant form and has been fueled by at least two factors. First, like Catholicism and Judaism in American history, Islam is confronting hostility as a new religion. Second, since the end of communism, radical Muslims have become the new nemesis of the USA. The backlash against Middle Eastern and Muslim Americans is not new. At least since the 1973 Arab oil embargo, anti-Americanism in the Middle East has ushered backlash. Other notable incidents include the Iran hostage crisis, the 1983 bombing of the US embassy in Beirut and the US marine barracks, the First Gulf War (1990-1), and the 1993 World Trade Center bombing. In particular, the 9/11 terrorist attack, the US involvement in wars in Afghanistan and Iraq, and the continuing Arab-Israeli conflict have made the backlash against Muslims in America particularly virulent (also see Shryock 2010).

In 2010, plans to establish an Islamic Center, the Park 51 project, a few blocks from the World Trade Center site of the September 112001 terrorist attacks in New York City sparked controversy and anti-Muslim sentiments. The center has been supported by many politicians at the local and national levels, including New York City Mayor Michael Bloomberg and President Barack Obama, as well as by religious leaders of many faiths. However, conservative politicians, Tea Party activists, and some of the 9/11 families and survivors opposed it, labeling it the "Ground Zero mosque." They argued that a mosque at this hallowed place would prevent the nation from healing. While the Park 51 project planned to include facilities for athletics, performances, and weddings, as well as a space for prayer, the opposition has been focused on "the mosque." These sentiments were fueled by fear of Islam and a belief that it is a violent religion that threatens the security of the USA.

While there is no unified "European response" to the perceived anxiety regarding Muslim immigrants, many countries have witnessed host hostility. Until the 1970s, France welcomed immigrants to fill labor demands. However, when the second generation demonstrated in 1983 for equality and end of racism, "Marche des Beurs," the French questioned their integration in intense debates (1983-5). Having established Le Front National (FN) far-right, nationalist political party in 1972, Jean-Marie Le Pen used immigration as a wedge issue in electoral campaigns. For example, in 1983, FN managed to change the outcome of small municipal elections in spite of its minuscule membership. His daughter, Marine Le Pen, continued this legacy in 2011.

Likewise in the UK, immigration was unrestricted for Europeans for most of the twentieth century, thus filling the gap in the unskilled labor market. Even the 1948 British Nationality Act enabled former empire subjects to live and work in the UK without a visa. In 1968, however, Conservative MP Enoch Powell began agitating for immigrants' stronger connections to the UK. He alleged that visa applicants established families with partners they never met because they were motivated by welfare benefits. While Powell was dismissed from his post as Shadow Defence Secretary for his racism, soon thereafter restricted citizenship codes for immigrants from the colonies were enacted. In the next section, we identify various causes of nativism and group them under political, social/cultural, and economic categories. 
Often hostilities emerge during periods of mass migration and economic downturns. Therefore, we compared the two main large-scale immigration waves to the USA at the turn of the twentieth century (1880-1930) and the turn of the twenty-first century (1965 to the present). Immigration to the USA has reoriented from South, Central, and Eastern Europe in the first wave to Asia, South and Central America, the Caribbean, Africa, and the Middle East in the second wave, resulting in far more diversity in contemporary immigration. The new immigrants are also more diverse in socioeconomic origins, with only some immigrants starting at the bottom of the ladder. In addition, the new immigrants are diverse religiously and have introduced new religions to America (e.g., Buddhism, Hinduism, Islam, and Sikhism). The outcome of all this diversity is that the immigrants no longer fit a simple stereotype and thus cannot be subjected to the same type of nativism that the pioneers encountered.

The dominant ideology of immigration has also changed from assimilation during the first wave to pluralism during the second. The new ideology does not expect immigrants to completely shed their cultural heritage or otherwise be subjected to societal ostracism. This does not mean that the assimilationists have disappeared from the scene. There is still a strong antiimmigrant current in the USA, though the nativists' targets are more specific. Undocumented migrants are the newest and the easiest targets.

\section{Economic causes of nativism}

While theories of intergroup relations are not specifically geared at explaining hostilities against immigrants, they are useful in examining the relationship between foreign and native-born groups. These theories have attributed the cause of conflict to competitive minority-majority relations in the host society. The "structural theory of ethnic competition," as formulated by Olzak and Nagel (1986), for example, deals with some form of economic or political contestation between groups. It demonstrates that ethnic conflict is caused by increased rivalry when inequalities between groups diminish. This would explain the rise of hate crimes in the 1980s as new immigrants attempted integration in predominantly white neighborhoods and institutions, threatening whites' privileged position and access to the scarce societal resources. It also explains anti-immigrant ordinances passed in small-town America as Latino immigrants have spanned across the nation to new destinations since the inception of the twenty-first century. For instance, Hazleton, Pennsylvania passed an anti-immigrant ordinance in 2006 which allowed businesses to investigate the immigration status of their employees, penalizing employers who did not comply with the ordinance. After it was struck down by a federal judge, Hazleton attempted to pass other anti-immigrant ordinances, unsuccessfully.

Edna Bonacich posited that ethnic hostility is derived in many instances from economic conflicts created by capitalist economies. She coined the term "split labor market theory" to explain this conflict, which she argues is an immediate result of high-priced labor (traditionally white males), and cheap labor (typically composed of new immigrants and ethnic minorities) in the USA (Bonacich 1972). In an attempt to minimize labor costs and increase profit, employers hire immigrant and ethnic minorities as cheap labor power. This creates animosity and frustration among the nativeborn labor force, which has historically led to anti-immigration sentiments and actions. The anti-Asian sentiment in the nineteenth century is a case in point. Initially, Chinese laborers were welcomed into the USA because of their cheap and cooperative labor. However, shortly after they became visible, white workers felt threatened by the competition. They began lobbying to restrict Chinese immigration to the USA and from working in mines and on the railroads.

Even after the passage of Civil Rights laws $(1964,1965)$ and the fact that two US presidents apologized for the Japanese internment during World War II, Asians continued to be targeted as 


\section{Bozorgmehr et al.}

the US economy suffered a downfall. In the 1980s and early 1990s, US industries began to lose to global competition, and never fully recovered. Politicians and media outlets blamed cheap imports, especially Japanese cars, for the failure of American industries. The imbalance of USJapanese trade fueled anti-Japanese sentiments among natives resulting in "Japan bashing." The brutal murder of Vincent Chin, a 27-year-old Chinese American in Detroit in 1982, was a vivid example of scapegoating. The assailants, two autoworkers (one recently laid off), called him a "Jap," and blamed him for the loss of their jobs. They received no time in jail.

Theorists have argued that "middleman minorities"- small business owners who straddle producers and consumers in modern economies-face host hostility because of their visible concentration in business. Their economic success can provoke hostility by the majority population and envy by disadvantaged minority groups (Bonacich and Modell 1980; Turner and Bonacich 1980; Gold 2010). The Los Angeles Riots of 1992 constitute a glaring American example of hostility against middleman minorities. Having established small businesses in predominantly African-American neighborhoods in South Central Los Angeles, Korean storeowners were resented by African Americans for hiring co-ethnics and Latino labor migrants, taking capital away from the black community, as well as ill treatment and lack of trust of black customers. About 2,300 Korean stores were destroyed at a cost approximately $\$ 785$ million. Leading Korean American scholar Pyong Gap Min has maintained that the anti-Korean hostility was due to their precarious middleman minority role (Min 1996).

In the post-1965 era, undocumented migration to the USA has emerged in the public imagination as the new economic threat. Douglas Massey notes that Mexican "illegal" migration began in 1965 and steadily increased from the mid-1960s in response to the collapse of both the Mexican economy and the end of the Bracero Program (Massey et al. 2002). The program was based on a binational treaty between the USA and Mexico that imported Mexican labor contractors to work in the agricultural sector in the USA because of the shortage of American farm workers during World War II (also see Ngai 2005).

In the 1990s, undocumented immigrants were accused of tapping into and depleting public resources despite the fact that many researchers have debunked the "loafer" myth. Available evidence shows that the undocumented shy away from using welfare programs out of fear of being caught and deported. Nonetheless, undocumented immigrants are scapegoated with a variety of policies and laws (Chavez 2008). Examples include the anti-immigration measures of the 1996 Welfare Reform Act, which restricted the access of even legal and permanent residents to services and public assistance. Another noteworthy example is Proposition 187 in California, euphemistically called the "Save our State" proposition. Proposed by Pete Wilson, the former governor of California in 1994, this anti-immigration measure sought to restrict illegal immigrants from accessing public services such as education and health care, except in emergency cases. It also charged social service agencies with gatekeeper responsibilities, thus criminalizing illegal immigrants. Proposition 187 was bogged down in the courts and was not passed as law on the grounds that immigration law is a federal not state matter (Sabagh and Bozorgmehr 2002).

Undocumented migrants are accused of not only exploiting public resources, but also taking jobs from hardworking Americans. In April 2010, Arizona passed the anti-immigration legislation SB 1070, which authorizes local law enforcement agents to check the immigration status of individuals suspected of being illegal immigrants. While the law is being challenged by the US Justice Department on the grounds that immigration law is federal not local, almost half of Americans oppose the Justice Department's actions. In August 2010, nativist proponents of SB 1070 sought to change the Fourteenth Amendment of the Constitution, which grants citizenship to children born in the USA. They feared that illegal immigrants would enter America's 
borders to give birth and thus gain naturalization through their children who have birthright citizenship.

Christian Joppke (2010), a specialist on immigration and citizenship in Europe, suggests that the tightening of immigration legislation coincided with economic downturns. Indeed, across Europe since the 1980s, states are deregulating their economies and dismantling their welfare system. Health care, postal services, public utilities (electricity, gas), public transportation, and telecommunication (telephones and the Internet) have been privatized. Even before these changes, many Europeans were feeling "compassion fatigue." For decades, many European states had open door policies and generous benefits toward refugees and asylees which attracted persons fleeing war and political crises. As a result, native Europeans became more anti-immigrant, blaming newcomers for numerous problems.

\section{Political causes of nativism}

Suspicion of new immigrants intensified during World War I (1914-18) because many originated from countries that had become the enemies of the USA. In particular, German immigrants, who were called "enemy aliens," were required to register and to be monitored by the state. Fifteen states passed laws making English the official language. Past admiration for German scientific and artistic accomplishments soon turned into hostility and race-based vilification of "Huns" or barbarians. German ethnic organizations were attacked, and nativist anger was aimed at all things German. The hysteria led to the banning of Beethoven's music in Boston, and the burning of German books in Lima, Ohio. Many German American institutions and organizations conformed to the demands of super-patriots. For example, Lutheran churches switched their service to English and many German Americans Anglicized their names. The upshot was their expedited assimilation (Kennedy 1980).

Political refugees and exiles who leave their country of origin because of their opposition to the regime often become scapegoats in the host society. Generally, political refugees tend to be caught in the middle of conflicts between sending and receiving societies. The Iranian case perhaps best exemplifies tenuous relations between sending and receiving nations in contemporary times.

After the Iranian Revolution of 1978-9, relations between the USA and Iran became strained, as Washington was a longtime supporter of Mohammad Reza Shah Pahlavi. When the exiled Shah entered the USA in October 1979 for medical care, many Iranians feared a repetition of the US-assisted coup that had put the Shah back on the throne in 1953. This concern instigated the "Iran Hostage Crisis," where a crowd of about 500 militants stormed the US embassy in Tehran on November 41979 and captured about 90 employees who were inside. Of these, 52 Americans were held hostage for 444 days until January 20, 1981. In retaliation, the federal government and several states enacted measures that specifically targeted Iranian students in the USA. In November 1979, the Attorney General, upon the direction of President Carter, required all Iranian nationals who were in the USA on student visas to report to the Immigration and Naturalization Service (INS) for registration by mid-December. Each nonimmigrant alien was required to provide proof of residence, full-time school enrollment, and a passport with a valid visa. The regulation implied that non-compliance would be considered a violation of the conditions of the alien's stay in the United States, thus grounds for deportation under the Immigration and Nationality Act. The hostage crisis prompted a presidential order known as the "Iranian Control Program," which screened almost 57,000 Iranian students, the single largest group of foreign students in the USA at the time. However, the program has had long-term consequences of restricting Iranian immigration to the USA. The closure of the 
American embassy in Iran to date forces Iranians to first travel to a transit country to obtain a US visa (Bozorgmehr 2000).

Bakalian and Bozorgmehr (2009) develop a theoretical model of backlash for the causes and consequences of host hostility during periods of war and/or political/ideological crises. In these hostile periods, the state tends to target a minority population that happens to share the same immigrant/ethnic or religious background as the "enemy." Such repressive measures rarely happen in a vacuum. The targeted group generally suffers from widespread scapegoating and stereotypes. Thus, there is a feedback loop between the hate crimes and bias incidents perpetrated by common people and the repressive policies of the state; both are mediated and reinforced through deeply seeded prejudice and discrimination. Backlash is defined as the combination of stereotypes, scapegoating, hate crimes and government initiatives. Backlash may give rise to mobilization or claims making in the short or long term. In the 9/11 case, the mobilization of the Middle Eastern and Muslim populations was relatively quick due to the existence of opportunity structures, namely the passage of civil rights laws, the Japanese redress movement, the emergence of oversight organizations such as the American Civil Liberties Union (ACLU), and the culture of pluralism in the USA (Schain 2008).

Political scientist Martin Schain argues that immigration dynamics on both sides of the Atlantic are politicized differently; they vary in how issues are framed and in their salience (Schain 2008). Since 9/11, Muslim immigrants' traditional behavior and religiosity have been perceived as a threat to national identity in France, Germany, and Great Britain (Joppke 2009), whereas the USA has problematized the undocumented (mostly from Latin America) and the porous Mexico border. Women donning the hijab, or more radically the niqab, in school and the workplace, have been subject to harassment, especially in France. In the 1990s, a number of girls were suspended from school for refusing to remove their hijab. The debates came to be known as l'affaire $d u$ voile. Teachers and others argued that displaying one's religious identity harms the unity and laïcité (secularism) of the French Republic. In 2011, the French centerright government banned the wearing of niqab or burqa. Those breaking the law would be fined 150 Euros or made to enroll in mandatory lessons in French citizenship. Immigration has also been an electoral hot-button issue in contemporary Europe. The emergence of small far-right political parties in the Netherlands, Austria, Denmark, and Luxembourg has forced moderates or centrists to accommodate to extremists to win elections. With the FN in France and the Conservative Party in Britain, the immigration of Muslims has been politicized, resulting in reexamination and critique of immigration and citizenship policies. In contrast, immigrants from Europe are seen as necessary for the labor market.

\section{Social and cultural causes of nativism}

Nativists believe that non-English languages are not part of the American culture and that language differences pose a threat to the American nation. This fear has been demonstrated throughout the twentieth century with calls for monolingualism and "English only" legislation, which gained national prominence in the 1980s and 1990s. These campaigns, led by politicians such as Japanese American senator S. I. Hayakawa, called for a constitutional amendment to make English the official language of the USA. Nativists fear that multilingualism is going to destabilize and balkanize the USA, like Canada for instance (Zolberg and Woon 1999). However, these fears are unwarranted. The consensus of researchers is that immigrant languages are lost altogether within three generations. Indeed, there is a decided preference for English speaking among the second generation and English monolingualism by the third (Portes and Rumbaut 2006). 
In the Netherlands, the pillarization system was used as the basis for the social institutions of the Dutch society according to religious groupings of Protestants and Catholics. The influx of Muslim immigrants in the 1960s and 1970s-mostly from Turkey and North Africa (Morocco, Algeria, and Tunisia) - coincided with the decline of the pillarization system. As a result, they were not able to develop a distinctive Muslim pillar, and have subsequently faced obstacles to their institutional claims for accommodation. Dutch society experienced several dramatic incidents of intergroup conflict such as the murder of film maker Theo van Gogh by a Dutch Moroccan in 2004, heralding much dread and debate about Islam in Holland. Muslims in the Netherlands have a long history, with the earliest wave of Muslim immigrants arriving from the Dutch East Indies in the nineteenth century. Labor shortages in the 1960s forced the government to import guest workers from Turkey and Morocco (Rath 2011). Even when the program ended in 1973, immigrants continued to arrive under family reunification provisions. Since the 1990s, the majority of newcomers have been refugees or asylum seeker from Muslim countries. Tolerance is a cherished value for the Dutch, who are proud of the harmonious coexistence that the Protestants and Roman Catholics in the Netherlands have and continue to enjoy. However, once the Muslims were no longer confined to their ethnic enclaves, especially the second generation, Dutch tolerance began to wane. The Dutch reacted with fear and hostility. The Muslims, who were seen as guests, were settling permanently and in large numbers, posing a threat to the Dutch way of life. Not surprisingly, when the Minister of Justice suggested in 2006 that the Netherlands should accept Shariah law, a massive outrage resulted.

\section{Consequences of nativism: exclusion, forced assimilation, and ethnic solidarity}

Throughout the history of American immigration, the first tendency of nativists has been to keep undesirable groups out by stopping all forms of immigration, expel illegal immigrants and constrain legal immigrants by depriving them of full citizenship rights bestowed upon native-born citizens. This ideology exhibits anxieties about the impact of the new waves of immigrants on American society. The 1924 quota law, Proposition 187 in California and SB 1070 in Arizona are examples.

The second nativist trend is "forced assimilation" (Portes and Rumbaut 2006). The classic example is the response of the USA to the massive wave of immigration at the turn of the twentieth century. As the economic well-being of the USA declined in the first two decades of the twentieth century, there were concerns that immigrants would not be able to adapt to the American way of life. To assuage their anxieties, the One Hundred Percent Americanization Movement was created. The Hundred Percenters became very popular, and was endorsed by President Theodore Roosevelt who warned against the dangers of "hyphenated Americans." Federal and state agencies embarked on a massive educational program including classes in the English language, citizenship, American history, and politics. The campaign to Americanize the uncouth masses involved lessons on personal and household hygiene, diet, fashion, and etiquette. The Anglo-Saxon middle class mainstream culture formed the standard for everyone and everything.

Advocates of Americanization recognize US immigrant history and the success of the immigrant experience in abandoning one's culture. Nativists believe that since the old immigrants, including their ancestors, assimilated rapidly, the cultural traditions and the languages of the newcomers are also expected to disappear by the second generation. They favor "English only" policies and often have unreasonable expectations of immigrants to speak unaccented English. While this movement appears to be inclusive, it has been counter-productive. 


\section{Bozorgmehr et al.}

Furthermore, what forced assimilationists neglect is that in an increasingly globalized world, knowledge of languages other than English is beneficial for citizens and nation states alike. For instance, America has a vital need for fluent Arabic speakers to fill intelligence services positions in the aftermath of $9 / 11$. Bilingualism and even multilingualism should be seen as an asset for the USA in the world. Although pluralism has replaced assimilation as the dominant ideology of majority-minority relations in the USA, the proponents of forced assimilation persevere.

In 2005, the European Union adopted a common agenda for integration. Jan Rath, a leading scholar of European immigration at the University of Amsterdam, notes that the Dutch expect immigrants to change and that the government has the power to enforce integration (Rath 2011). Germany, the Netherlands, and the UK have even developed citizenship tests, which suggest that there is a single national and cultural standard for citizenship and belonging. This is strongly implied in the material covered in the test preparation kits. For example, test takers should know that nude swimming is legal in the Netherlands. To sensitize them to become tolerant Dutch, immigrants are shown images of topless women and men kissing. In Germany, a draft test queried the opinion of applicants on forced marriage, homosexuality, and women's rights, all of which were questions that extend beyond knowledge of civic duties. Migrants are increasingly tested on their value systems in the path to becoming citizens.

Nonetheless, in spite of the fear of Muslim extremists and anti-Islamic rhetoric, the immigrant populations are integrating. In France, the rate of intermarriage among the second generation is relatively high. Moreover, states have been silently accommodating many of the claims of their Muslim citizens through human rights litigation. For instance, a German hijabi woman sued a well-known department store company for firing her as a cosmetic salesperson. The success of her case has opened the door to other claimants to defend their individual rights to practice their religion in a liberal democratic state. While most European societies assume that integration is one-sided, astute entrepreneurs realize that there is a lucrative market to serve. Albert Heijn, the largest supermarket company in Holland, has its Turkish, Moroccan, and Pakistani employees wearing headscarves in the company's colors, symbolizing that their business is Muslim-friendly. In France, there are newly established halal retail stores that feature non-pork pate and sausages for upwardly mobile native Muslims.

Intransigent nativism often has the opposite effect for the host society. It gives rise to ethnic solidarity, defined as collective action on the part of minority groups to advance their goals and objectives. For instance, the Japanese American Citizens League (JACL) mobilized Japanese Americans after the war for the recognition of and reparation for the internment camps, and formed the Commission on Wartime Relocation and Internment of Civilians. Their campaign culminated in the Civil Liberties Act of 1988, which provided monetary compensation of $\$ 20,000$ to each victim if alive, or an heir if deceased and a formal apology.

The well-known Simmel-Coser theorem states host hostility creates internal group solidarity (Coser 1956). While true in terms of group cohesion and ethnic retention, ethnic solidarity has only recently taken effect in response to new nativism. This is mainly due to structural conduciveness of post-Civil Rights America to ethnic and racial minority claims making. The post-9/11 backlash illustrates a new trend in mobilization among targeted populations. Civil Rights Laws $(1964,1965)$ have changed the playing field for all minority groups by creating a more conducive environment for claims making. While it took the Japanese a long time to mobilize against their internment, Middle Eastern and Muslim Americans immediately mobilized against the 9/11 backlash and claimed their rightful place in American society. Middle Eastern and Muslim Americans distanced themselves from the terrorists and condemned the $9 / 11$ terrorist attacks. They demonstrated their allegiance to the USA by engaging in 
outreach, educating the American public about both the Middle East and the Muslim faith, and engaging their community members in political advocacy (Bakalian and Bozorgmehr 2009).

Other examples of ethnic solidarity include the collective mobilization by Mexican and Hispanic communities in California against Proposition 187 in 1994. The Mexican American Legal Defense and Educational Fund (MALDEF), organized naturalization and voting registration campaigns, producing a shift in the electoral power of Mexican Americans in California by electing young Democratic Mexican politicians costing conservative Republican politicians their seats. In 2005, Republicans sponsored the bill H.R. 4437, Border Protection, Antiterrorism and Illegal Immigration Control Act, in an attempt to criminalize undocumented workers, their employers and anyone who provides them with assistance. The bill also sought to build a fence along the entire US-Mexican border. In response, Mexican and Mexican American groups and civil right organizations, labor unions, and the Catholic Church organized large civic protests and marches in Los Angeles, Chicago, Phoenix, and Washington, DC, as well as other metropolitan areas in the USA. The bill never became law (Hondagneu-Sotelo 2008).

\section{Conclusion}

This chapter has dealt with host hostility in major immigrant-receiving advanced industrial countries. While the main focus is on the USA, we have used Europe to show similarities and differences. Nativism has been used as a concept to depict host hostility. In spite of keen interest in nativism and its persistence, there are few publications on the subject, and much of it is historical and descriptive in nature. Our goal was to review the existing literature on host hostility and nativism, and organize it conceptually and theoretically. We started by mapping the landscape of hosts, guests, and hostility. Although often treated as a homogeneous entity, the host comprises several components, namely the state, the majority population and the native-born ethnic/racial minorities, each of which can engage in anti-immigrant animosity. The guests are immigrants, refugees, and their descendants (ethnic minority groups). Hostility and nativism run the full gamut from scapegoating, stereotypes, prejudice, discrimination, and racism, to hate crimes, bias incidents, and government initiatives.

There are at least three major sources of nativism: economic, political, and social/cultural. Although these reasons are often combined in reality, we examine each separately for analytical purposes. Economic reasons entail labor market competition, middleman minority status, global economic competition, undocumented migration and in general some form of intergroup competition for scarce resources. Some of these economic roots of conflict are more theoretically developed than others, so we summarize them here. The wage and salaried immigrants allegedly compete for menial jobs with the native-born minorities in inner cities. The selfemployed who hold a middleman minority position, face conflict with native-born minorities and are accused of hiring co-ethnics and labor migrants rather than unemployed native-born minorities. Political reasons often involve hostilities between the sending and receiving countries, especially during times of war and international crises.

American and European societies have manifested their persistent nativism in a variety of ways. Two dominant forms are forced assimilation and integration of immigrants (English-language only movements) or exclusion of the newcomers (anti-immigrant legislation). One of the new and unintended consequences of hostility has been ethnic solidarity among the targeted groups, defined as collective action or claims making to achieve specific aims. While in the old days, nativism resulted in involuntary and forced assimilation, it now may result in ethnic solidarity. Nativists unintentionally help immigrant groups and especially their descendants to lay claims to 
their rights and find a place in host societies. Hopefully, in the long run, this will reduce if not eradicate host hostility and nativism in the USA and Europe.

\section{References and further reading}

Alba, R. and Nee, V. (2003) Remaking the American Mainstream. Cambridge, MA: Harvard University Press.

Bail, C. A. (2008) "The configuration of symbolic boundaries against immigrants in Europe" American Sociological Review 73(1): pp. 37-59.

Bakalian, A. and Bozorgmehr, M. (2009) Backlash 9/11: Middle Eastern and Muslim Americans Respond. Berkeley, CA: University of California Press.

Blalock, H. (1967) Toward a Theory of Minority Group Relations. New York: John Wiley and Sons.

Bonacich, E. (1972) "A theory of ethnic antagonism: the split labor market" American Sociological Review 37(5): $547-59$.

Bonacich, E. and Modell, J. (1980) The Economic Basis of Ethnic Solidarity: Small Business in the Japanese American Community. Berkeley, CA: University of California Press.

Bozorgmehr, M. (2000) "Does host hostility create ethnic solidarity? The experience of Iranians in the United States" Bulletin of the Royal Institute for Inter-Faith Studies (BRIIFS) 2(1): 159-78.

Brimelow, P. (1995) Alien Nation: Common Sense about America's Immigration Disaster. New York: Random House.

Camp, H. C. (1995) Iron in Her Soul: Elizabeth Gurley Flynn and the American Left. Pullman, WA: Washington State University Press.

Castles, S. and Miller, M. (2008) Age of Migration, 4th edition. New York: Guilford.

Cesari, J. (2004) When Islam and Democracy Meet: Muslims in Europe and the United States. New York: Palgrave.

Chavez, L. R. (2008) The Latino Threat: Constructing Immigrants, Citizens, and the Nation. Stanford, CA: Stanford University Press.

Cornell, S. E. and Hartmann, D. (1998) Ethnicity and Race: Making Identities in a Changing World. Thousand Oaks, CA: Pine Forge Press.

Coser, L. A. (1956) The Functions of Social Conflict: An Examination of the Concept of Social Conflict and its Use in Empirical Sociological Research. New York: The Free Press.

Daniels, R. (1972) Concentration Camps USA: Japanese Americans and World War II. New York: Holt, Rinehart and Winston.

-(1988) Asian Americans: Chinese and Japanese in the United States since 1850. Seattle, WA University of Washington Press.

Diner, H. R. (1999) Jews in America. New York: Oxford University Press.

Foner, N. and Alba, R. (2008) "Immigrant religion in the US and Western Europe: Bridge or barrier to inclusion?" International Migration Review 42(2): 360-92.

Gold, S. J. (2010) The Store in the Hood: A Century of Ethnic Business and Conflict. Lanham, MD: Roman and Littlefield.

Gerstle, G. (2004) "The immigrants as threat to American security: A historical perspective." In J. Tirman (ed.), The Maze of Fear: Security and Migration after 9/11. New York: New Press, pp. 87-108.

Higham, J. (1955) Strangers in the Land: Patterns of American Nativism, 1860-1925. New Brunswick, NJ: Rutgers University Press.

Hondagneu-Sotelo, P. (2008) God's Heart Has No Borders: Religious Activism for Immigrant Rights. Berkeley, CA: University of California Press.

Jaret, C. (1995) Contemporary Racial and Ethnic Relations. New York: Harper Collins.

— (2002) "Troubled by newcomers: Anti-immigrant attitudes and actions during two eras of mass migration." In P. G. Min (ed.), Mass Migration to the United States. Walnut Creek, CA: Altamira Press.

Joppke, C. (2009) Veil: Mirror of Identity. Boston, MA: Polity Press, pp. 21-63.

-(2010) Citizenship and Immigration. Boston, MA: Polity Press.

Kennedy, D. M. (1980) Over Here: The First World War and American Society. New York: Oxford University Press.

Koopmans, R., Statham P., Giugni M., and Passy, F. (2005) Contested Citizenship: Immigration and Cultural Diversity in Europe. Minneapolis, MN: University of Minnesota Press.

Massey, D. S., Durand J., and Malone, N. J. (2002) Beyond Smoke and Mirrors: Mexican Immigration in an Era of Economic Integration. New York: Russell Sage. 
Min, P. G. (1996) Caught in the Middle: Korean Communities in New York and Los Angeles. Berkeley, CA: University of California Press.

Min, P. G. (ed.) (2005) Encyclopedia of Racism in the United States [Three Volumes]. Westport, CT: Greenwood Press.

Modood, T. (2005) Multicultural Politics: Racism, Ethnicity, and Muslims in Europe. Minneapolis, MN: University of Minnesota Press.

Ngai, M. (2005) Impossible Subjects, Illegal Aliens and the Making of Modern America. Princeton, NJ: Princeton University Press.

Olzak, S. and Nagel, J. (eds) (1986) Competitive Ethnic Relations. Orlando, FL: Academic Press.

Portes, A. and Rumbaut, R. G. (2006) Immigrant America: A Portrait, 3rd edition. Berkeley, CA: University of California Press.

Rath, J. (2011) "Debating multiculturalism: Europe's reaction in context" Harvard International Review http://hir.harvard.edu/debating multiculturalism (accessed January 6 2011).

Sabagh, G. and Bozorgmehr, M. (2002) 'From 'give me your poor' to 'save our state': New York and Los Angeles as immigrant cities and regions.” In D. Halle (ed.), New York and Los Angeles: Politics, Society and Culture. Chicago, IL: University of Chicago Press, pp. 99-123.

Sanchez, G. (1999) "Face the nation: Race, immigration, and the rise of nativism in late twentieth century America." In C. Hirschman, P. Kasinitz, and J. DeWind (eds), The Handbook of International Migration: The American Experience. New York: Russell Sage, pp. 371-82.

Schain, M. A. (2008) The Politics of Immigration in France, Britain and the United States: A Comparative Study. New York: Palgrave.

Shryok, A. (2010) Islamophobia/Islamophilia: Beyond the Politics of Enemy and Friend. Bloomington, IN: Indiana University Press.

Turner, J. and Bonacich, E. (1980) "Toward a composite theory of middleman minorities" Ethnicity 71(1): 144-58.

Vertovec, S. and Wessendorf, S. (eds) (2009) The Backlash Against Multiculturalism: European Discourses, Practices and Policies. London, UK: Routledge.

Zolberg, A. R. (2006) A Nation by Design: Immigration Policy in the Fashioning of America. New York: Russell Sage.

Zolberg, A. R. and Litt Woon, L. (1999) "Why Islam is like Spanish: Cultural incorporation in Europe and the United States" Politics and Society 27(1): 5-38. 